\title{
Nontechnical Barriers to Solar Energy Use: Review of Recent Literature
}

Technical Report NREL/TP-520-40116

September 2006

R. Margolis and J. Zuboy 


\section{Nontechnical Barriers to Solar Energy Use: Review of Recent Literature}

R. Margolis and J. Zuboy

Prepared under Task No. PVC6.1301

Technical Report NREL/TP-520-40116

September 2006

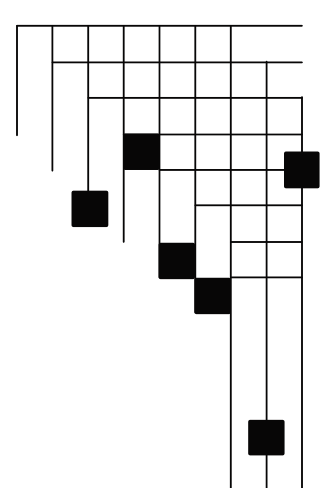




\section{NOTICE}

This report was prepared as an account of work sponsored by an agency of the United States government. Neither the United States government nor any agency thereof, nor any of their employees, makes any warranty, express or implied, or assumes any legal liability or responsibility for the accuracy, completeness, or usefulness of any information, apparatus, product, or process disclosed, or represents that its use would not infringe privately owned rights. Reference herein to any specific commercial product, process, or service by trade name, trademark, manufacturer, or otherwise does not necessarily constitute or imply its endorsement, recommendation, or favoring by the United States government or any agency thereof. The views and opinions of authors expressed herein do not necessarily state or reflect those of the United States government or any agency thereof.

Available electronically at http://www.osti.gov/bridge

Available for a processing fee to U.S. Department of Energy and its contractors, in paper, from:

U.S. Department of Energy

Office of Scientific and Technical Information

P.O. Box 62

Oak Ridge, TN 37831-0062

phone: 865.576 .8401

fax: 865.576 .5728

email: mailto:reports@adonis.osti.gov

Available for sale to the public, in paper, from:

U.S. Department of Commerce

National Technical Information Service

5285 Port Royal Road

Springfield, VA 22161

phone: 800.553.6847

fax: 703.605.6900

email: orders@ntis.fedworld.gov

online ordering: http://www.ntis.gov/ordering.htm 


\section{Introduction}

In this paper, we review the nontechnical barriers to solar energy use. Specifically, we draw on recent literature to help identify key barriers that must be addressed as part of the Technology Acceptance efforts under the U.S. Department of Energy (DOE) Solar America Initiative. ${ }^{1}$ A broad literature search yielded more than 400 references, which we narrowed to 19 recent documents on nontechnical barriers to the use of solar energy and other energy efficiency and renewable energy (EE/RE) technologies. The following were the most frequently identified barriers:

- Lack of government policy supporting EE/RE

- Lack of information dissemination and consumer awareness about energy and EE/RE

- High cost of solar and other EE/RE technologies compared with conventional energy

- Difficulty overcoming established energy systems

- Inadequate financing options for EE/RE projects

- Failure to account for all costs and benefits of energy choices

- Inadequate workforce skills and training

- Lack of adequate codes, standards, and interconnection and net-metering guidelines

- Poor perception by public of renewable energy system aesthetics

- Lack of stakeholder/community participation in energy choices and EE/RE projects.

Below we describe our methodology, the documents reviewed, and the barriers most frequently identified. In addition, annotated references include detailed information for each of the key documents, including the technologies considered, the method of barrier identification, the geographic focus, a summary of the document, and the barriers identified.

\section{Methodology}

To identify the relevant literature, we conducted key word searches in a number of databases:

- Academic Search Premier

- Business Source Premier

- Energy Citations Database (DOE Office of Scientific and Technical Information)

- EconLit

- Engineering Village (Compendex)

- Information Sciences Institute (ISI) Web of Science

- ISI Current Contents Connect

- National Renewable Energy Laboratory (NREL) publications database

- World Wide Web (Google), limited search.

We used two general strategies to search the databases, although each database required slight variations in search technique based on its structure. The first strategy used the terms (solar or renewable or photovoltaic) and barrier(s). The second strategy used the terms (solar or

\footnotetext{
${ }^{1}$ For information about the Solar America Initiative see www.eere.energy.gov/solar/solar america.
} 
renewable or photovoltaic) and institutional and (policies or policy). For some of the databases, the term energy was added to narrow the results to more relevant documents. Because the EE/RE field is evolving rapidly, we limited our searches to documents published in 2000 or later. These searches yielded more than 400 references.

We then narrowed the full list of references based on the following criteria:

- Documents focusing on technical barriers to solar energy and other EE/RE technologies (e.g., inability to make high-efficiency photovoltaic [PV] cells on low-quality material) were excluded.

- Documents related to developing countries (e.g., India and Bangladesh) were excluded, because these countries have considerably different market conditions compared with industrialized countries like the United States.

- Documents related to industrialized countries other than the United States were included but only when the barriers discussed were not too country-specific, i.e. barriers had to be general enough to apply to EE/RE issues in the United States.

- Documents were limited to those that had a specific purpose in the identification of multiple barriers and performed this task via explicitly identified information-gathering and analytical methods and sources. Numerous documents and Web sites mention barriers tangentially and others describe barriers in detail without citing methods and sources.

- Documents that generated a list of barriers based solely on review of past literature were excluded. Included documents had to contain some form of original research or analysis.

We considered documents addressing a variety of EE/RE technologies when these documents included solar technologies or included other EE/RE technologies with similar challenges to those faced by solar technologies. In addition, we considered documents cited within each of the references in the narrowed list. Ultimately, we identified 19 key references for inclusion in this report.

In this report, we focus on nontechnical barriers to solar energy use, including those referred to as "market," "institutional," and "policy" barriers. However, nontechnical and technical barriers can be related. For example, the barrier of high cost is affected by technical factors, such as PV sunlight-to-electricity conversion efficiency and manufacturing yield, as well as nontechnical factors, such as supply and demand. In the annotated references below, technical barriers are excluded when the documents explicitly distinguished between technical and nontechnical barriers. When the documents did not make this distinction, lists that mix predominantly nontechnical with predominantly technical barriers are left intact. Still, because of the documents selected, the most frequently identified barriers are predominantly nontechnical in nature.

Discussing solutions to the identified barriers is outside the scope of this report. However, most of the documents listed offer strategies for overcoming barriers, and it is worthwhile to explore these documents further. In addition, most of the documents contain references to other valuable documents about EE/RE topics. 


\section{Documents Reviewed}

The 19 documents reviewed represent a range of sources, EE/RE technologies, analytical and information-gathering methods, and geographic areas of interest (Table 1). Eleven are papers from peer-reviewed journals, including nine from the journal Energy Policy. Of the remaining documents, one is an American Society of Mechanical Engineers proceedings paper, and seven are reports from the following organizations: DOE, Energy Trust of Oregon, Florida Solar Energy Center, NREL, Solar Electric Power Association (two reports), and Solar Energy Industries Association.

All of the documents address solar technologies (PV, solar thermal, and unspecified "solar"), including nine that exclusively cover solar technologies. Among the other EE/RE technologies addressed, the most frequently mentioned are biomass, wind, hydroelectricity, geothermal, tidal, and wave. Mentioned in one document each are hydrogen from renewable sources, combined heat and power, thermal energy stored in aquifers, ambient heat, hybrid-drive vehicles, and energy efficiency. Some of these documents discuss specific characteristics of the different types of technologies, whereas others merely list the technologies as examples of what constitutes "renewable energy."

The methods used in the reviewed documents to identify barriers fall into two broad categories: analysis and feedback. These methods are not mutually exclusive; most documents use both (e.g., Foxon et al. 2005) but emphasize one over the other. The most frequently used form of analysis is energy policy analysis, found mostly in the Energy Policy papers. For example, Fuchs and Arentsen (2002) analyze electricity policy and its effect on renewable energy using a "coevolutionary approach," which integrates consumer and producer perspectives and the role of interactive learning in technology development. Other analyses are in the context of finance (Goldman et al. 2005), economics (Neuhoff 2005), and architectural design (Sozer and Elnimeiri 2003).

Feedback methods include focus groups, workshops, interviews, "lessons learned," and surveys. For example, Solar Energy Industries Association (2003) and Solar Electric Power Association (2002) contain insights from extensive "roadmapping" processes, in which numerous public and private stakeholders contributed their experience and expertise via focus groups, workshops, and interviews. Florida Solar Energy Center (2000), Tombari (2005), and Willey et al. (2001) are "lessons learned" documents resulting from collaborative solar energy projects. Faiers and Neame (2006) surveyed solar energy adopters and nonadopters to discover the differences between the two groups.

The United States is the primary geographic area of interest, with 10 of the reviewed documents focusing on the United States. Three documents have a regional focus, including Europe and North America, OECD, and the world. Five focus on specific non-U.S. countries-Australia, Greece, the Netherlands, and the United Kingdom (two documents) - and another does not specify a geographic focus. See Table 1 and the annotated references for more detail on sources, $\mathrm{EE} / \mathrm{RE}$ technologies, methods, and geographic areas of interest. 
Table 1. Summary of documents reviewed

\begin{tabular}{|c|c|c|c|c|c|}
\hline Author(s) & Source & $\begin{array}{l}\text { Source } \\
\text { type }\end{array}$ & Technologies & Method & $\begin{array}{l}\text { Geographic } \\
\text { focus }\end{array}$ \\
\hline Brown (2001) & $\begin{array}{l}\text { "Market Failures and Barriers as a Basis } \\
\text { for Clean Energy Policies," Energy Policy }\end{array}$ & $\begin{array}{l}\text { Peer- } \\
\text { reviewed } \\
\text { journal }\end{array}$ & $\begin{array}{l}\text { Energy efficiency and } \\
\text { renewable energy }\end{array}$ & Energy policy analysis & United States \\
\hline $\begin{array}{l}\text { Dymond } \\
(2002)\end{array}$ & PV Focus Group Report & $\begin{array}{l}\text { Energy } \\
\text { Trust of } \\
\text { Oregon } \\
\text { report }\end{array}$ & PV & $\begin{array}{l}\text { PV stakeholder focus } \\
\text { groups }\end{array}$ & $\begin{array}{l}\text { United States } \\
\text { (Oregon) }\end{array}$ \\
\hline $\begin{array}{l}\text { Faiers \& } \\
\text { Neame } \\
(2006)\end{array}$ & $\begin{array}{l}\text { "Consumer Attitudes Towards Domestic } \\
\text { Solar Power Systems," Energy Policy }\end{array}$ & \begin{tabular}{|l|} 
Peer- \\
reviewed \\
journal
\end{tabular} & Solar thermal, PV & $\begin{array}{l}\text { Survey of solar energy } \\
\text { adopters and non- } \\
\text { adopters }\end{array}$ & $\begin{array}{l}\text { United } \\
\text { Kingdom }\end{array}$ \\
\hline FSEC (2000) & $\begin{array}{l}\text { Florida Photovoltaic Buildings Program: } \\
\text { Status Report, Observations and Lessons } \\
\text { Learned }\end{array}$ & $\begin{array}{l}\text { FSEC } \\
\text { report }\end{array}$ & PV (buildings focus) & $\begin{array}{l}\text { Observations from } 2 \text { years } \\
\text { of Florida PV Buildings } \\
\text { Program }\end{array}$ & $\begin{array}{l}\text { United States } \\
\text { (Florida) }\end{array}$ \\
\hline $\begin{array}{l}\text { Foxon et al. } \\
\text { (2005) }\end{array}$ & $\begin{array}{l}\text { "UK Innovation Systems for New and } \\
\text { Renewable Energy Technologies: } \\
\text { Drivers, Barriers and Systems Failures," } \\
\text { Energy Policy }\end{array}$ & $\begin{array}{l}\text { Peer- } \\
\text { reviewed } \\
\text { journal }\end{array}$ & $\begin{array}{l}\text { Wind, wave, tidal, } \mathrm{PV} \text {, } \\
\text { biomass, hydrogen from } \\
\text { renewable sources, } \\
\text { district and micro-CHP }\end{array}$ & $\begin{array}{l}\text { Analysis of innovation } \\
\text { systems for new and } \\
\text { renewable energy } \\
\text { technologies, interviews of } \\
\text { UK stakeholders }\end{array}$ & $\begin{array}{l}\text { United } \\
\text { Kingdom }\end{array}$ \\
\hline $\begin{array}{l}\text { Fuchs \& } \\
\text { Arentsen } \\
\text { (2002) }\end{array}$ & $\begin{array}{l}\text { "Green Electricity in the Market Place: } \\
\text { The Policy Challenge," Energy Policy }\end{array}$ & \begin{tabular}{|l|} 
Peer- \\
reviewed \\
journal
\end{tabular} & $\begin{array}{l}\text { Wind, solar, biomass, } \\
\text { geothermal, small-scale } \\
\text { hydroelectric }\end{array}$ & Energy policy analysis & $\begin{array}{l}\text { Europe and } \\
\text { North } \\
\text { America }\end{array}$ \\
\hline $\begin{array}{l}\text { Goldman et } \\
\text { al. (2005) }\end{array}$ & $\begin{array}{l}\text { Financing Projects That Use Clean- } \\
\text { Energy Technologies: An Overview of } \\
\text { Barriers and Opportunities }\end{array}$ & $\begin{array}{l}\text { NREL } \\
\text { report }\end{array}$ & $\begin{array}{l}\text { Clean energy } \\
\text { technologies (e.g., } \\
\text { ethanol plant, PV } \\
\text { manufacturing facility, } \\
\text { landfill-gas electricity } \\
\text { generation) }\end{array}$ & Financial analysis & United States \\
\hline $\begin{array}{l}\text { Heiman \& } \\
\text { Solomon } \\
(2004)\end{array}$ & $\begin{array}{l}\text { "Power to the People: Electric Utility } \\
\text { Restructuring and the Commitment to } \\
\text { Renewable Energy," Annals of the } \\
\text { Association of American Geographers }\end{array}$ & $\begin{array}{l}\text { Peer- } \\
\text { reviewed } \\
\text { journal }\end{array}$ & $\begin{array}{l}\text { Wind, biomass, solar, } \\
\text { geothermal, and small- } \\
\text { scale hydroelectric }\end{array}$ & Energy policy analysis & United States \\
\hline $\begin{array}{l}\text { Jacobsson \& } \\
\text { Johnson } \\
(2000)\end{array}$ & $\begin{array}{l}\text { "The Diffusion of Renewable Energy } \\
\text { Technology: An Analytical Framework } \\
\text { and Key Issues for Research," Energy } \\
\text { Policy }\end{array}$ & \begin{tabular}{|l|} 
Peer- \\
reviewed \\
journal
\end{tabular} & $\begin{array}{l}\text { Biomass, wind, solar } \\
\text { thermal, PV }\end{array}$ & Energy policy analysis & $\begin{array}{l}\text { OECD } \\
\text { (European } \\
\text { emphasis) }\end{array}$ \\
\hline Menz (2005) & $\begin{array}{l}\text { "Green Electricity Policies in the United } \\
\text { States: Case Study," Energy Policy }\end{array}$ & \begin{tabular}{|l|} 
Peer- \\
reviewed \\
journal
\end{tabular} & $\begin{array}{l}\text { Wind, solar, } \\
\text { geothermal, small-scale } \\
\text { hydropower, biomass }\end{array}$ & Energy policy analysis & United States \\
\hline $\begin{array}{l}\text { Neuhoff } \\
(2005)\end{array}$ & $\begin{array}{l}\text { "Large-Scale Deployment of Renewables } \\
\text { for Electricity Generation," Oxford Review } \\
\text { of Economic Policy }\end{array}$ & \begin{tabular}{|l|} 
Peer- \\
reviewed \\
journal
\end{tabular} & $\begin{array}{l}\text { Solar, wind, tidal, wave, } \\
\text { geothermal, } \\
\text { hydroelectric, biomass }\end{array}$ & Economic analysis & $\begin{array}{l}\text { World (OECD } \\
\text { emphasis) }\end{array}$ \\
\hline
\end{tabular}




\begin{tabular}{|c|c|c|c|c|c|}
\hline $\begin{array}{l}\text { Sidiras \& } \\
\text { Koukios } \\
(2004)\end{array}$ & $\begin{array}{l}\text { "Solar Systems Diffusion in Local } \\
\text { Markets," Energy Policy }\end{array}$ & $\begin{array}{l}\text { Peer- } \\
\text { reviewed } \\
\text { journal }\end{array}$ & $\begin{array}{l}\text { Solar domestic hot } \\
\text { water systems }\end{array}$ & $\begin{array}{l}\text { Questionnaires plus } \\
\text { document research, } \\
\text { interviews, workshops }\end{array}$ & Greece \\
\hline SEPA & $\begin{array}{l}\text { Solar Power Solutions: A Business Case } \\
\text { for Capturing Total Value }\end{array}$ & $\begin{array}{l}\text { SEPA } \\
\text { report }\end{array}$ & PV (utility focus) & $\begin{array}{l}\text { Collective views of } \\
\text { industry/sector experts, } \\
\text { industry roadmap projects, } \\
\text { PV history review }\end{array}$ & United States \\
\hline SEIA & $\begin{array}{l}\text { Solar Electric Power-The U.S. } \\
\text { Photovoltaic Industry Roadmap }\end{array}$ & $\begin{array}{l}\text { SEIA } \\
\text { report }\end{array}$ & PV & $\begin{array}{l}\text { Industry-government- } \\
\text { university workshops }\end{array}$ & United States \\
\hline $\begin{array}{l}\text { Sonneborn } \\
(2004)\end{array}$ & $\begin{array}{l}\text { "Renewable Energy and Market-Based } \\
\text { Approaches to Greenhouse Gas } \\
\text { Reduction - Opportunity or Obstacle?" } \\
\text { Energy Policy }\end{array}$ & $\begin{array}{l}\text { Peer- } \\
\text { reviewed } \\
\text { journal }\end{array}$ & $\begin{array}{l}\text { PV, solar thermal, wind, } \\
\text { hydroelectric, wave, } \\
\text { tidal, biomass-derived } \\
\text { liquid fuels, biomass- } \\
\text { fired electric generation }\end{array}$ & Energy policy analysis & Australia \\
\hline $\begin{array}{l}\text { Sozer \& } \\
\text { Elnimeiri } \\
(2003)\end{array}$ & $\begin{array}{l}\text { "Identification of Barriers to PV } \\
\text { Application into the Building Design," } \\
\text { Proceedings of the } 2003 \text { International } \\
\text { Solar Energy Conference }\end{array}$ & $\begin{array}{l}\text { ASME } \\
\text { proceedings }\end{array}$ & Building-integrated PV & $\begin{array}{l}\text { Architectural design } \\
\text { analysis }\end{array}$ & Unspecified \\
\hline $\begin{array}{l}\text { Tombari } \\
(2005)\end{array}$ & $\begin{array}{l}\text { Become One In A Million: Partnership } \\
\text { Updates, Million Solar Roofs and } \\
\text { Interstate Renewable Energy Council } \\
\text { Annual Meeting }\end{array}$ & $\begin{array}{l}\mathrm{DOE} \\
\text { report }\end{array}$ & $\begin{array}{l}\text { PV, solar water heating, } \\
\text { transpired solar } \\
\text { collectors, solar space } \\
\text { heating and cooling, } \\
\text { pool heating }\end{array}$ & $\begin{array}{l}\text { Reports from Million Solar } \\
\text { Roofs partnerships }\end{array}$ & United States \\
\hline $\begin{array}{l}\text { van Rooijen } \\
\text { \& van Wees } \\
(2006)\end{array}$ & $\begin{array}{l}\text { "Green Electricity Policies in the } \\
\text { Netherlands: An Analysis of Policy } \\
\text { Decisions," Energy Policy }\end{array}$ & $\begin{array}{l}\text { Peer- } \\
\text { reviewed } \\
\text { journal }\end{array}$ & $\begin{array}{l}\text { Wind, PV, solar thermal, } \\
\text { geothermal, thermal } \\
\text { energy storage in } \\
\text { aquifers, ambient heat, } \\
\text { hydroelectricity, } \\
\text { biomass, wave, tidal }\end{array}$ & Energy policy analysis & $\begin{array}{l}\text { The } \\
\text { Netherlands }\end{array}$ \\
\hline $\begin{array}{l}\text { Willey et al. } \\
(2001)\end{array}$ & TEAM-UP Final Reports & $\begin{array}{l}\text { SEPA } \\
\text { Report }\end{array}$ & PV (utility focus) & $\begin{array}{l}\text { Interviews with TEAM-UP } \\
\text { participants, review of final } \\
\text { venture reports from } \\
\text { TEAM-UP, SEPA } \\
\text { presentations and } \\
\text { publications }\end{array}$ & United States \\
\hline
\end{tabular}

ASME—American Society of Mechanical Engineers; FSEC-Florida Solar Energy Center; OECD—Organisation for Economic Co-operation and Development; SEIA—Solar Energy Industries Association; SEPA—Solar Electric Power Association. 


\section{Nontechnical Barriers Identified}

Below is a list of the most frequently identified nontechnical barriers to use of solar energy and other $\mathrm{EE} / \mathrm{RE}$ technologies. The number in parentheses is the number of documents identifying the barrier, out of 19. Barriers with asterisks are expanded briefly following the list; the others are self-explanatory. For more information, see the annotated references and the original sources.

- Lack of government policy supporting EE/RE (13)*

- Lack of information dissemination and consumer awareness about energy and EE/RE (12)

- High cost of solar and other EE/RE technologies compared with conventional energy (10)

- Difficulty overcoming established energy systems (10)*

- Inadequate financing options for EE/RE projects (10)

- Failure to account for all costs and benefits of energy choices $(8)^{*}$

- Inadequate workforce skills and training (7)*

- Lack of adequate codes, standards, and interconnection and net-metering guidelines (5)

- Poor perception by public of renewable energy system aesthetics (4)

- Lack of stakeholder/community participation in energy choices and EE/RE projects (4)

*Lack of government policy supporting EE/RE. This includes the lack of policies and regulations supporting development of solar and other EE/RE technologies and the presence of policies and regulations hindering EE/RE development and supporting conventional energy development. Examples include fossil-fuel subsidies, insufficient consumer-based EE/RE incentives, government underwriting for nuclear plant accidents, and difficult zoning and permitting processes for renewable energy.

*Difficulty overcoming established energy systems. This includes difficulty introducing innovative energy systems, particularly for distributed generation such as PV, because of technological lock-in, electricity markets designed for centralized power plants, and market control by established generators.

*Failure to account for all costs and benefits of energy choices. This includes failure to internalize all costs of conventional energy (e.g., effects of air pollution, risk of supply disruption) and failure to internalize all benefits of EE/RE (e.g., cleaner air, energy security).

*Inadequate workforce skills and training. This includes lack in the workforce of adequate scientific, technical, and manufacturing skills required for EE/RE development; lack of reliable installation, maintenance, and inspection services; and failure of the educational system to provide adequate training in new technologies

\section{Acknowledgments}

We thank Al Berger and Suzette Cohn of the NREL Library for their assistance with the literature search. 


\section{Annotated References}

1. Brown, M.A. (November 2001). "Market Failures and Barriers as a Basis for Clean Energy Policies.” Energy Policy (29:14); pp. 1197-1207.

Technologies considered: Energy efficiency and renewable energy

Method: Energy policy analysis; draws on Scenarios for a Clean Energy Future by the Interlaboratory Working Group (2000)

Geographic focus: United States

\section{Summary}

This paper describes the cost-effective energy efficiency opportunities that could be realized by overcoming the market failures and barriers that are causing an "efficiency gap" (the gap between actual investment in energy efficiency and the higher level that would be economically beneficial to consumers).

\section{Barriers identified}

Market failures (flaws as compared with an "ideal market")

- Misplaced incentives: energy decisions made by an agent of the consumer are not in the consumer's best interest (e.g., a landlord does not install energy-efficient appliances because the renter pays the energy bills)

- Distortionary fiscal and regulatory policies: policies remove incentives for energy efficiency (e.g., not setting energy prices based on time-of-use discourages consumers from using energy more efficiently during high-price periods)

- Unpriced costs: not figuring the negative impacts of energy into its cost (e.g., the effects of air pollution from fossil fuel combustion)

- Unpriced benefits: not figuring the positive impacts of energy into its cost (e.g., the reduced air pollution due to cleaner energy production)

- Insufficient and inaccurate information: consumers not informed about energy (e.g., electricity bills do not detail the energy consumption of specific end uses)

Market barriers (nonmarket failure barriers that hinder energy efficiency implementation)

- Low priority of energy issues: conventional energy is still relatively cheap, and consumers typically do not understand negative externalities of conventional energy

- Capital market barriers: limited access to capital and high interest rates can inhibit energy efficiency improvements

- Incomplete markets for energy efficiency: energy efficiency is an inseparable part of many products, limiting consumer choice (e.g., fuel economy is not a separate option for automobiles)

Also see: Interlaboratory Working Group (November 2000). Scenarios for a Clean Energy Future. ORNL/CON-476, LBNL-44029. Oak Ridge, TN: Oak Ridge National Laboratory; Berkeley, CA: Lawrence Berkeley National Laboratory, (www.ornl.gov/sci/eere/cef/). This extensive analysis by five national laboratories underpins Brown's (2001) paper. 
2. Dymond, C. (October 2002). PV Focus Group Report. Portland, OR: Energy Trust of Oregon.

Technologies considered: PV

Method: Focus groups

Geographic focus: United States (Oregon)

\section{Summary}

This report summarizes findings from seven focus-group meetings held in 2002 throughout Oregon with people involved in PV delivery, education, and installation (6-10 people per focus group). The purpose was to learn about market barriers, opportunities, and requirements from people knowledgeable about PV in preparation for launching a PV program in Oregon. The consensus barriers are shown below.

\section{Barriers identified}

- High initial up-front cost is biggest barrier to PV

- Financing difficult to get; need easy access and a consistent approach to financing

- Difficult path to PV: current implementation of PV systems requires significant consumer knowledge and patience; need a set of steps for making an intelligent $\mathrm{PV}$ purchase decision; also need easily accessible incentives

- Lack of training: trained, qualified installers and inspectors needed

- Lack of communication: potential customers must hear consistent message about merits of PV from many sources so they are confident to make the purchase; accessible demonstration projects should be used to communicate $\mathrm{PV}$ information to the public

- Lack of credibility: need credible endorsements of PV to instill consumer confidence; implicit endorsements include utility PV programs and government tax credits

- Inconsistent inspection process: inspection process varies by community and should be streamlined to reduce delays

- Current Oregon and federal tax structure favors commercial systems

- Failure to account for full value: ancillary value of PV must be emphasized, e.g., added resale value for homes with PV, pride of ownership, status, and environmental value

Link: www.energytrust.org/Pages/about/library/reports/02 PVFocusGroup.pdf 
3. Faiers, A.; Neame, C. (September 2006). "Consumer Attitudes Towards Domestic Solar Power Systems.” Energy Policy (34:14); pp. 1797-1806.

Technologies considered: Solar thermal, PV

Method: Surveys administered to 100 solar power "early adopters" and 1,000 members of the assumed solar power "early majority" in the United Kingdom; differences between the groups' attitudes indicate barriers to solar power adoption

Geographic focus: United Kingdom

\section{Summary}

This paper uses Diffusion of Innovations theory to determine attitudes toward characteristics of solar systems and barriers to adoption. Surveys were administered to two types of homeowner in central England: "early adopters" (who have already purchased solar power systems) and an assumed "early majority" (who have invested in energy efficiency measures but not solar power). Attitudes toward various characteristics of solar power systems are isolated to determine which characteristics are preventing the pragmatic early majority from adopting solar power. Recommendations for bridging the "chasm" between the early adopters and early majority are given.

\section{Barriers identified}

- Poor aesthetics

- High cost

- Insufficient government grants for solar power purchase

- Too much maintenance required

- Does not add value to property

- Difficult installation 
4. Florida Solar Energy Center (March 2000). Florida Photovoltaic Buildings Program: Status Report, Observations and Lessons Learned. Cocoa, FL: Florida Solar Energy Center.

Technologies considered: PV (buildings focus)

Method: Observations and lessons learned from the Florida PV Buildings Program

Geographic focus: United States (Florida)

\section{Summary}

This report summarizes observations and lessons learned from 2 years of operating the Florida PV Buildings Program, a collaborative effort among the Florida Energy Office of the Department of Community Affairs, Sandia National Laboratories, the PV industry, the Florida Solar Energy Center, and nine end-user groups: municipal utilities and rural electric cooperatives, commercial building owners and operators, government and public agencies, school and church organizations, manufactured building corporations, investor-owned utilities and energy service companies, commercial roofing companies, builders and developers, and homeowners and buyers.

\section{Barriers identified}

- Difficult interconnection: cumbersome and inappropriate interconnection requirementsincluding technical, insurance, metering, and billing issues - are single greatest barrier to development of market for customer-owned, grid-tied PV systems

- Lack of communication: must communicate relevant technical information regarding personnel safety, equipment protection, power quality, and reliability of service to utilities

- Liability: some utilities more concerned about precedence setting and liability than technical issues; some utilities in Florida and across the United States are using the liability insurance issue to stop PV system installations

- Resistance to net metering: utilities expressed concerns about net metering and appear unwilling to yield

- High cost: need direct sales of multiple PV systems to utilities to bring down costs; standardizing and packaging of PV systems needed to bring installed prices down; transaction costs for individual sales of grid-tied PV systems are very high and make technology unattractive to many potential end users

Link: www.fsec.ucf.edu/pvt/Resources/publications/pdf/LESSONSLEARNED.PDF 
5. Foxon, T.J.; Gross, R.; Chase, A.; Howes, J.; Arnall, A.; Anderson, D. (November 2005). "UK Innovation Systems for New and Renewable Energy Technologies: Drivers, Barriers and Systems Failures.” Energy Policy (33:16); pp. 2123-2137.

Technologies considered: Wind (onshore and offshore), marine (wave and tidal), PV, biomass, hydrogen from renewable sources, district and micro-CHP (combined heat and power)

Method: Analysis of UK innovation systems for new and renewable energy technologies, including interviews of UK academic, industry, and policy stakeholders

Geographic focus: United Kingdom

\section{Summary}

This paper summarizes results from a 2003 study commissioned by the UK Department of Trade and Industry. It examines the systemic processes by which innovation occurs related to UK new and renewable energy technologies. It identifies gaps preventing technologies from moving along the innovation chain and provides policy recommendations for facilitating successful commercialization of new and renewable energy technologies.

\section{Barriers identified}

- Difficulty moving from demonstration projects to more substantial, pre-commercial deployment

- Insufficient financing for scale-up to next stage

- Different skills required for people involved with large-scale demonstration and early commercialization vs. skills required for R\&D and initial demonstration

- Difficulty moving from pre-commercial deployment to supported commercialization because of unfavorable risk/reward ratio

- Technology risk: risk of technology not achieving expected performance and cost

- Market risk: risk that future levels of reward will be insufficient

- Regulatory risk: risk that market will change due to changing government policies

- Systems risk: risk for disruptive technologies, that existing technological or institutional systems will not change to accommodate the new technologies

- Difficulty protecting intellectual property (IP), including registration of patents

- Particularly a challenge for small companies

- IP is valuable for securing private financing

- Worries about IP can prevent companies from collaborating with universities

- Lack of necessary scientific and technical skills in the national (UK) workforce

Also see: Imperial College Centre for Energy Policy and Technology; E4Tech (June 2003). The UK Innovation Systems for New and Renewable Energy Technologies, Report for UK Department of Trade and Industry. London, UK: UK Department of Trade \& Industry (www.dti.gov.uk/files/file22069.pdf). This report underpins the Foxon et al. (2005) paper. 
6. Fuchs, D.A.; Arentsen, M.J. (May 2002). "Green Electricity in the Market Place: The Policy Challenge.” Energy Policy (30:6); pp. 525-538.

Technologies considered: Wind, solar, biomass, geothermal, small-scale hydroelectric

Method: Energy policy analysis

Geographic focus: Europe and North America

\section{Summary}

This paper describes the coevolutionary approach to analyzing technological innovation, then uses this approach to analyze barriers to and strategies for increasing the production and consumption of electricity from renewable sources.

\section{Barriers identified}

Barriers to renewable electricity production: technological inertia

- Difficulty integrating renewable electricity generation with the dominant central-station generation system because of restricted controllability and manageability of renewable sources

- Inability of renewable sources to achieve the scale necessary to become a significant component of large-scale electricity systems, i.e. the scale of electricity demand is too large compared with the scale of electricity supply renewable sources can provide

- Tendency of electrical systems only to integrate innovations that do not deviate too much from dominant technological trajectories (e.g., biomass is more easily accepted because it employs a similar technology as fossil fuel combustion)

- Likelihood of energy market liberalization leading to further development of currently operating generation technologies

Barriers to renewable electricity consumption: technology and consumption "lock-in"

- Lock-in of consumers into conventional electricity consumption patterns, i.e. receiving electricity from a monopoly provider without need to make choices

- Lack of consumer knowledge about electricity supply options as well as their own electricity consumption and its environmental consequences

- Presence of network externalities for early adopters, i.e. individual choices make little difference to overall environmental impact of electricity production

- Tendency of consumers to see choices about environmental impacts of electricity as the responsibility of utilities and regulators

- Differences in consumption styles (e.g., the style of "eco-niche" families vs. that of mainstream, "inconspicuous" families) make communication and diffusion of electricity consumption choices across diverse groups of people difficult 
7. Goldman, D.P., McKenna J.J., Murphy, L.M. (October 2005). Financing Projects That Use Clean-Energy Technologies: An Overview of Barriers and Opportunities. NREL/TP-60038723. Golden, CO: National Renewable Energy Laboratory.

Technologies considered: Clean energy technologies (e.g., ethanol plant, PV manufacturing facility, apartment water-metering equipment, landfill-gas electricity generation, hybrid-electric delivery trucks)

Method: Financial analysis

Geographic focus: United States

\section{Summary}

This report summarizes the importance of project financing for clean energy technology deployment as well as key challenges to financing clean energy projects and ways to address these challenges.

\section{Barriers identified}

- Risks associated with financing clean energy projects

- Technology risk: concern that a technology will underperform or become obsolete prematurely; lack of information/experience to make comparisons with other energy technologies

- Creditworthiness risk: concern by lenders about project's ability to service debt from project cash flow; lack of maturity of company and technology, and lack of proven acceptance in the marketplace

- Revenue security risk: need for revenue security over the time required to pay back capital investment

- Market competition risk: concern by financiers about high capital cost of clean energy projects and lower cash flows compared with traditional energy sources

- Small-scale and related cost issues: competitive disadvantage of clean energy projects because they are smaller than traditional energy projects, making the impact of due-diligence and transaction costs much greater on the smaller projects

Link: www.nrel.gov/docs/fy06osti/38723.pdf 
8. Heiman, M.K.; Solomon, B.D. (March 2004). "Power to the People: Electric Utility Restructuring and the Commitment to Renewable Energy." Annals of the Association of American Geographers (94:1); pp. 94-116.

Technologies considered: Wind, biomass, solar, geothermal, small-scale hydroelectric

Method: Energy policy analysis

Geographic focus: United States

\section{Summary}

This paper reviews U.S. energy policy and its weaknesses with respect to reducing man-made carbon dioxide emissions. It examines electricity market reform and its effects on renewable energy use. It uses experiences from the United States and Western Europe to make policy recommendations that promote renewable energy.

\section{Barriers identified}

- Cost of extending transmission lines to remote generation sites

- Price distortions owing to recapture of stranded costs for noncompetitive plants and infrastructure

- Lack of "Community Choice" allowing aggregate default switching to a municipal electricity supplier

- Conventional electricity subsidies including lack of accountability for social and environmental costs of conventional generation

- Intermittent nature of renewable energy 
9. Jacobsson, S.; Johnson, A. (July 2000). "The Diffusion of Renewable Energy Technology: An Analytical Framework and Key Issues for Research.” Energy Policy (28:9); pp. 625-640.

Technologies considered: Biomass, wind, solar thermal, PV

Method: Energy policy analysis

Geographic focus: OECD (European emphasis)

\section{Summary}

This paper describes renewable energy technologies and their growth rates, then uses an innovation system perspective to provide an analytical framework for studying how these new technologies may transform the energy sector. It also outlines issues that must be researched to understand the transformation of the energy system into one that employs more renewable energy.

\section{Barriers identified}

Actors and markets

- Poorly articulated demand: consumers unable to articulate price/performance demand during early stage of technology diffusion

- Disadvantage vs. established technology: established technology has benefited from experience and economies of scale, so newer technologies tend to have higher price or lower utility in comparison

- Local search processes: companies tend to build on their existing technological base when making improvements instead of pursuing new, less-known technologies

- Market control by incumbents: market control by dominant incumbents can hinder consumers' choice of new technologies

Networks

- Poor connectivity: companies are not well connected to other companies with an overlapping technology base

- Wrong guidance about future markets: individual companies are guided by the network in wrong directions, or the network fails to share required knowledge among companies

Institutions

- Legislative failures: legislation creates bias toward established technologies

- Educational system failures: educational system supports current technologies over potential new technologies or fails to react quickly enough to emergence of new technologies

- Skewed capital market: supply of capital does not emerge spontaneously in response to needs of emerging technology

- Underdeveloped organizational and political power of new entrants: including lack of industry organizations and ways to share information 
10. Menz, F.C. (December 2005). "Green Electricity Policies in the United States: Case Study." Energy Policy (33:18); pp. 2398-2410.

Technologies considered: Wind, solar, geothermal, small-scale hydropower, biomass

Method: Energy policy analysis

Geographic focus: United States

\section{Summary}

This paper reviews and discusses the major U.S. electricity sources, the changing regulatory environment for the electricity industry, U.S. government policies used to promote green electricity, and factors influencing the development of green power markets.

\section{Barriers identified}

- Relatively high cost of electricity from renewable energy sources

- Price distortions due to unaccounted-for external costs or direct subsidies

- Lack of customer awareness about renewable energy products

- Relative abundance of conventional energy sources 
11. Neuhoff, K. (2005). "Large-Scale Deployment of Renewables for Electricity Generation." Oxford Review of Economic Policy (21:1); pp. 88-110.

Technologies considered: Solar, wind, tidal, wave, geothermal, hydroelectric, biomass

Method: Economic analysis

Geographic focus: World (OECD emphasis)

\section{Summary}

This paper summarizes the resource potential of renewable energy technologies, examines economic barriers to renewable energy, and provides recommendations for government policies related to renewable energy.

\section{Barriers identified}

"Uneven playing field," i.e., direct and indirect subsidies for conventional energy

- Inexpensive domestic energy rates

- Export credit guarantees for conventional energy

- Government underwriting of accidents for nuclear plants

- Failure to internalize environmental costs of conventional energy

- Failure to internalize risks of supply disruption from importing fossil fuels

- Failure to internalize energy security benefits of renewable sources

Market barriers

- Electricity market designed for conventional, centralized power plants

- Wind, solar, and wave energy output cannot be predicted accurately enough at the time of the liquid day-ahead market, thus these sources sell at lower prices than they should

- Electricity companies will manipulate energy market—selling above cost in short-term market when renewable output is low and buying below cost in long-term market when renewable output is high - reducing renewable energy revenue and creating production inefficiencies

- Vertically integrated companies have incentive to obstruct renewable energy if it benefits conventional/existing assets

- Less-capable companies increase cost of decentralized generation by using inappropriate procedures

- Renewable energy sources are small compared with required infrastructure expansion, i.e. it can be cost prohibitive to install infrastructure solely for a small renewable energy project

- Regulatory constraints on long-term electricity contracts create a risk premium that affects capital-intensive technologies, such as renewables and nuclear, more than technologies with high fuel costs, such as fossil fuel plants

- Regulators reinforce bias against capital-intensive technologies by failing to reward the small contribution of intermittent sources toward meeting peak demand

- Short-term electricity market contracting reinforces cyclical investment patterns that hinder small industries 
- Historical actuarial data are not available for assessing risk of new renewable energy technologies

- Small scale of renewable energy projects results in disproportionately high transaction costs for risk management tools, complex financing arrangements, or export credit guarantees Nonmarket barriers

- Administrative frameworks not tailored to renewable energy, e.g., complications due to zoning issues, permitting processes

- Lack of comprehensive information about renewable energy distributed to the public and other stakeholders and lack of citizen involvement in early stages of renewable energy deployment

Technology lockout, i.e. processes that favor established over innovative technologies

- Without large-scale deployment, cost of innovative technologies remains high and investors continue to use established technologies

- Renewable energy technologies produce same product as established technologies: electricity

- Energy projects are large and expensive, increasing risk; and established energy technologies have decades more market experience and investment than renewables

- Renewable energy innovators are not fully rewarded because of "technology spillover" (where other companies adopt the innovation and reap inexpensive benefits)

- Difficult to adequately define engineering patents to protect intellectual property

- The scale, capabilities required, and timeframe required to establish a renewable energy system and "learn by doing" requires a consortium of companies, but companies are reluctant to invest for the benefit of other consortium members 
12. Sidiras, D.K.; Koukios, E.G. (December 2004). "Solar Systems Diffusion in Local Markets." Energy Policy (32:18); pp. 2007-2018.

Technologies considered: Solar domestic hot water systems

Method: Document research and questionnaires, interviews, and workshops with the Greek government, scientific/technical community, solar industry, and consumers (questionnaires were the primary tool)

\section{Geographic focus: Greece}

\section{Summary}

This paper examines the driving forces and barriers related to the rapid implementation of solar domestic hot water systems (SDHWS) in Greece. Preliminary research using official documents and other sources identified driving forces and barriers. SDHWS stakeholders (homeowners, hotels/hostels, solar experts, and the solar industry) ranked the driving forces and barriers via questionnaires.

\section{Barriers identified}

- High cost

- Not owning the building where SDWHS would be installed

- Other priorities

- High payback period

- Difficult installation

- High maintenance cost

- Opinion of friends

- Aesthetics

- Others 
13. Solar Electric Power Association (April 2002). Solar Power Solutions: A Business Case for Capturing Total Value. Annandale, VA: Global Environment \& Technology Foundation.

Technologies considered: PV (utility focus)

Method: Collective views of industry and sector experts, recent industry roadmap projects, review of PV history

Geographic focus: United States

\section{Summary}

This report is a PV roadmap from the utility perspective. It focuses on factors aimed at bringing about successful PV implementation. It provides historical context about U.S. PV efforts as well as market analysis and recommendations. Sources include a wide range of people in the PV industry, energy providers, active PV communities, and government officials.

\section{Barriers identified}

- High initial cost of PV systems

- Unfavorable institutional structures and perceptions

- Regulatory barriers

- Negative public perception

- Inadequate installation and service infrastructure

- Inadequate financing options

- Lack of consumer knowledge about PV

- Lack of institutional familiarity with the technology

- Failure to translate consumer interest into action

- Lack of industry-offered systems to meet consumer needs and concerns

- Trends in conventional electricity costs

- Dominance of PV manufacturing and deployment by other countries

- Unresolved technology-development issues

- Technological bottlenecks for PV products and system components (e.g., inverters)

- Changing electricity infrastructure and distributed energy resources

- Inability to engage energy providers in PV deployment

Link: www.resourcesaver.com/file/toolmanager/O63F30134.pdf 
14. Solar Energy Industries Association (January 2003, reprinted). Solar Electric Power-The U.S. Photovoltaic Industry Roadmap. Washington, DC: Solar Energy Industries Association.

Technologies considered: PV

Method: Industry-government-university workshops

Geographic focus: United States

\section{Summary}

The roadmap - developed with industry, government, and university input - is a vision and planning document for U.S. PV research, technology, manufacturing, applications, market development, and policy through 2020. It includes a chapter on technical, market, and institutional barriers (market and institutional barriers discussed below).

\section{Barriers identified}

Market barriers

- Lack of consumer awareness and understanding

- Disincentives against net metering

- Lack of purchasing channels

- Lack of trained installers and inspectors

- Inadequate codes and standards related to PV

- Minimal financing options for PV systems

Institutional barriers

- Lack of communication within industry in identifying common technical problems

- Insufficiently trained and available PV manufacturing labor force

- No PV appliance ratings/standards

- Interconnection standards that inhibit PV development

- Inconsistent government policy related to PV

Link: $\underline{\text { www.nrel.gov/ncpv/pdfs/30150.pdf }}$

Also see: Solar Energy Industries Association (September 2004). Our Solar Power Future: The U.S. Photovoltaics Industry Roadmap Through 2030 and Beyond. Washington, DC: Solar Energy Industries Association. Some of the barriers shown above are implicitly reiterated in this 2004 version of the Industry Roadmap. 
15. Sonneborn, C.L. (November 2004). "Renewable Energy and Market-Based Approaches to Greenhouse Gas Reduction - Opportunity or Obstacle?” Energy Policy (32:16); pp. 1799-1805.

Technologies considered: PV, solar thermal, wind, hydroelectric, wave, tidal, biomass-derived liquid fuels, biomass-fired electric generation

Method: Energy policy analysis

Geographic focus: Australia

\section{Summary}

This paper analyzes the use of renewable energy to offset greenhouse gas emissions (GHG) in Australia under a market-based GHG-reduction approach. It argues that the Australian renewable energy sector is disadvantaged by market distortions and lack of policy support, and suggests actions the government and renewable energy industry can take to promote use of renewable energy for GHG reduction.

\section{Barriers identified}

- Subsidies supporting fossil fuel interests: Australian fossil fuel interests have received subsidies historically and continue to receive R\&D support; renewable energy does not receive equal assistance

- Lack of consideration of externalities: failing to account for externalities of energy consumption creates a false comparison between the cost of renewable energy and the cost of fossil fuels

- Obstacles to distributed generation: technical and electricity market barriers inhibit distributed electricity generation such as provided by renewable energy sources 
16. Sozer, H; Elnimeiri, M. (2003). "Identification of Barriers to PV Application into the Building Design." Proceedings of the 2003 International Solar Energy Conference; March 1518, 2003, Kohala Coast, Hawaii. New York, NY: American Society of Mechanical Engineers; pp. 527-533.

Technologies considered: Building-integrated PV

Method: Architectural design analysis

Geographic focus: Unspecified

\section{Summary}

This paper defines the architectural design process and identifies barriers to incorporating building-integrated PV in the process. Suggestions are given for overcoming the barriers.

\section{Barriers identified}

- Lack of integration with typical building process: including lack of integration with building materials, the building design process, codes and standards, the organizational structure (i.e. lack of awareness of PV by architects, engineers, contractor, facility manager, and owner), and building components (constructability, aesthetics, service/performance, and cost)

- Lack of common language: undefined language among various building professionals creates a gap between PV technology and the architectural design process

- Mismatched potential: this includes mismatch between energy needs of the building and capability/productivity of the PV system, between architectural design specifications and PV characteristics, between system durability and local climate, and between aesthetics of the PV system and aesthetics of the building and surroundings

- Unknown performance: the value of electricity generated by the building-integrated PV system is difficult to assess, making it difficult to secure financing

- Lack of economic analysis: Building an economic case for building-integrated PV is hindered by lack of complete financial and technical data, including cost-reducing factors (e.g., energy cost savings, tax credits, and increased rents) and hard-to-quantify benefits (e.g., enhanced power reliability, improved public image, and improved visual impact) 
17. Tombari, C. (September 2005). Become One In A Million: Partnership Updates, Million Solar Roofs and Interstate Renewable Energy Council Annual Meeting. DOE/GO-1020052177. Washington, DC: U.S. Department of Energy.

Technologies considered: PV, solar water heating, transpired solar collectors, solar space heating and cooling, pool heating

Method: Reports from Million Solar Roofs partnerships

Geographic focus: United States

\section{Summary}

This report highlights recent activities by 94 Million Solar Roofs partnerships from across the United States. It includes a summary of partnership-identified solar technology market barriers, which were found to be consistent across the country and similar to barriers faced by other distributed energy technologies.

\section{Barriers identified}

- High initial capital cost

- Lack of consumer awareness

- Utility interconnection issues

- Inadequate industry capacity: including lack of qualified installers, lack of solar information in the building industry and local government, and need to repair old or "orphaned" solar systems

Link: $\underline{\text { www.nrel.gov/docs/fy05osti/38587.pdf }}$ 
18. van Rooijen, S.N.M.; van Wees, M.T. (January 2006). "Green Electricity Policies in the Netherlands: An Analysis of Policy Decisions.” Energy Policy (34:1); pp. 60-71.

Technologies considered: Wind, PV, solar thermal, geothermal, thermal energy storage in aquifers, ambient heat, hydroelectricity, biomass, wave, tidal

Method: Energy policy analysis

Geographic focus: The Netherlands

\section{Summary}

This paper analyzes the three phases of Dutch renewable energy policy. It offers explanations as to why the renewable energy market in the Netherlands has remained small and why renewable energy targets have not been met.

\section{Barriers identified}

- Lack of a stable renewable energy investment climate

- Failure of the Dutch government to reduce market uncertainties and build investor confidence due to unclear and unstable policy goals and procedures

- Lack of meaningful stakeholder participation in Dutch energy policy making 
19. Willey, T., Hester, S., et al. (December 2001). TEAM-UP Final Reports. GFO report \# FC36-93CH10560. Washington, DC: Solar Electric Power Association.

Technologies considered: PV (utility focus)

Method: Interviews with TEAM-UP participants, review of final venture reports from TEAMUP rounds 1 through 3 and various Solar Electric Power Association presentations and publications

Geographic focus: United States

\section{Summary}

These six reports document information gained from the 35 TEAM-UP

(Technology Experience to Accelerate Markets in Utility Photovoltaics) ventures-TEAM-UP was a DOE-utility industry cost-shared program, started in 1994, focused on installing and demonstrating PV systems.

\section{Barriers identified}

- High cost and lack of adequate government incentives/subsidies to reduce cost

- Lack of marketing: lack of consumer education; lack of emphasis on nonfinancial benefits of PV

- Installation and maintenance issues: lack of electricians trained in PV; general lack of familiarity with PV among relevant personnel; lack of standardized interconnection requirements

- Lack of equitable net-metering guidelines

- Lack of financing incentives that make PV purchases easier

- Lack of community involvement and support

- Lack of compatibility between components, leading to below-expectations performance

- Lack of PV equipment supply

- Aesthetics issues: homeowners worried about appearance of PV; systems optimized for appearance not performance

Link: www.osti.gov/bridge/servlets/purl/794223-9v3sYT/webviewable/794223.pdf

Also see: Willey, T., Hester, S. (2003). "Solar Electric Technologies and Applications." Cogeneration and Competitive Power Journal (18:2); pp. 37-47. This journal article summarizes some of the barriers shown above. 


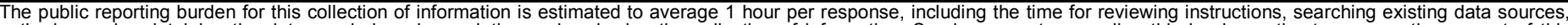

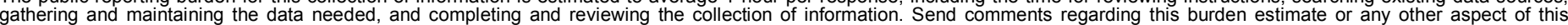

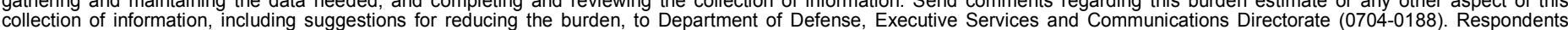

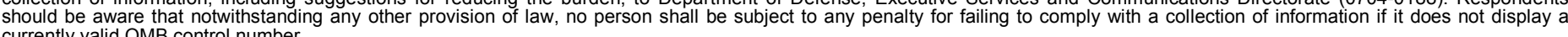

PLEASE DO NOT RETURN YOUR FORM TO THE ABOVE ORGANIZATION.

\begin{tabular}{l|l|l|l} 
1. REPORT DATE $(D D-M M-Y Y Y Y)$ & 2. & REPORT TYPE & 3. DATES COVERED (FrOm - TO)
\end{tabular}

September 2006

Technical Report

4. TITLE AND SUBTITLE

Nontechnical Barriers to Solar Energy Use: Review of Recent

Literature

5a. CONTRACT NUMBER

DE-AC36-99-G010337

5b. GRANT NUMBER

5c. PROGRAM ELEMENT NUMBER

6. AUTHOR(S)

R. Margolis and J. Zuboy

5d. PROJECT NUMBER

NREL/TP-520-40116

5e. TASK NUMBER

PVC6.1301

5f. WORK UNIT NUMBER
7. PERFORMING ORGANIZATION NAME(S) AND ADDRESS(ES)

National Renewable Energy Laboratory

1617 Cole Blvd.

Golden, CO 80401-3393

9. SPONSORING/MONITORING AGENCY NAME(S) AND ADDRESS(ES)
8. PERFORMING ORGANIZATION REPORT NUMBER

NREL/TP-520-40116
10. SPONSOR/MONITOR'S ACRONYM(S) NREL

11. SPONSORING/MONITORING AGENCY REPORT NUMBER

12. DISTRIBUTION AVAILABILITY STATEMENT

National Technical Information Service

U.S. Department of Commerce

5285 Port Royal Road

Springfield, VA 22161

13. SUPPLEMENTARY NOTES

14. ABSTRACT (Maximum 200 Words)

This paper reviews the nontechnical barriers to solar energy use, drawing on recent literature to help identify key barriers that must be addressed as part of the Technology Acceptance efforts under the U.S. Department of Energy (DOE) Solar America Initiative. A broad literature search yielded more than 400 references, which were narrowed to 19 recent documents on nontechnical barriers to the use of solar energy and other energy efficiency and renewable energy (EE/RE) technologies. Some of the most frequently identified barriers included lack of government policy supporting EE/RE, lack of information dissemination and consumer awareness about energy and EE/RE, high cost of solar and other EE/RE technologies compared with conventional energy, and inadequate financing options for EE/RE projects.

15. SUBJECT TERMS

solar energy; Solar America Initiative; literature search; energy efficiency; renewable energy; nontechnical barriers; energy use; technology acceptance; Robert Margolis; Jarett Zuboy

\begin{tabular}{|c|c|c|}
\hline 6. & CLAS & \\
\hline $\begin{array}{l}\text { a. REPORT } \\
\text { Unclassified }\end{array}$ & $\begin{array}{l}\text { b. ABSTRACT } \\
\text { Unclassified }\end{array}$ & $\begin{array}{l}\text { c. THIS PAGE } \\
\text { Unclassified }\end{array}$ \\
\hline
\end{tabular}

17. LIMITATION
OF ABSTRACT
UL

\begin{tabular}{l|l} 
18. NUMBER & 1 \\
OF PAGES &
\end{tabular}

19a. NAME OF RESPONSIBLE PERSON

19b. TELEPHONE NUMBER (Include area code) 